UDC 72/75:910.4

\author{
Olena M. Som-Serdyukova, \\ $\mathrm{PhD}$ in Arts, Associate Professor, \\ Stavanger, Norway, \\ e-mail: olenasom@gmail.com, \\ ORCID: http://orcid.org/ 0000-0001-5192-545X
}

\title{
KARLO ZVIRYNSKYI AND HIS «UNDERGROUND ACADEMY»: REFLECTIONS OF CULTURAL MEMORY
}

\begin{abstract}
Karlo Zvirynskyi (1923-1997) was an outstanding personality and great artist. His influence on the Lviv cultural environment in the 1960s-1990s was indisputable. Zvirynskyi was a quiet man rooted in his own research fields, but the awareness of his actions formed a strong environment in the aesthetics of the European art and ethical norms of Christianity. The artist's undiverted view on European culture was related to the understanding of processes that cannot be guided ideologically, as well as the realization that culture exists in continuity, and reflects aesthetical and ethical forms of human activity. His search for a European cultural tradition and the reprobation of foundations of socialist realism played an important role in the formation of his "underground academy". Zvirynskyi's primary goal was the education of creative young people as citizens, whose consciousness would enable them to remain artists in defiance of the enticing society. The circle of his students embraced Zinoviy Flinta, Andriy Bokotey, Oleh Minko, Liubomyr Medvid, Roman Petruk, Ivan Marchuk and Bohdan Soyka. Our task, for now, is not to embalm the legacy of his "underground academy", but create the cultural space, where intellectual reflections can take place. Karlo Zvirynskyi understood his stand in life as "I look at life through the prism of a book" and his artistic position as "all my painting is a prayer". Attitude to his own life as a part of a holistic cultural flow has formed his worldview. The cultural memory of generations that
\end{abstract}


accumulates "modernity" played for the artist a territory of freedom, which has always been a criterion of human nature for Zvirynskyi. Realizing that memory about Karlo Zvirynskyi is a kind of tuning fork for the moral health of the nation, this article is an attempt to bring knowledge about the master from the chamber community, which resembles the mechanisms of catacomb culture, in a wider and more open space that will use his name as part of the national cultural landscape.

Key words: artist, "underground academy", reflection, cultural memory, study, education, knowledge, intellectual, aesthetic, ethic, cultural landscape

Introduction. While thinking, analysing, and remembering everything related to the figure of Karlo Zvirynskyi in my life, I mentally recur to the phrase of Joseph Brodsky: A free man does not mean a happy man. And through the prism of time, I still understand that for these two giants of culture who have passed away, the criterion of freedom was comprehended as the starting point of humaneness. And it was the point only from which occurred the counting out of abilities, talents, accomplishments, and the scribing of people's own destinies.

Problem statement. In the realm of the 1960s-1990s Lviv artistic culture, Karlo Zvirynskyi not only has played a huge role but also has virtually become a component of its cultural landscape. His personality, as an artist and teacher, is partially outlined within the general Ukrainian context; however, studying this topic is still far from completion. He thought of himself as part of the Halychyna culture, yet his field of interests and acquaintance with the European culture, philosophy, music, and fine arts definitively take the master to another level of modern perception and rethinking of him.

An important point in reinterpreting his activities and heritage is a form of his existence as an artist and teacher. And here we should note that in fact, these two occupations, for Zvirynskyi, were almost merged together. Both of them were indispensable for 
the artist; in their interaction, he examined the quality of his own thoughts and the potency of formal visual expression. In addition, being confident in his ethical and aesthetic attitudes, Zvirynskyi realized that the moral degradation of society proffered by the system could be diminished. This would happen if he personally took on the task of educating young people not only within the frame of official teaching, but also in a private form of conversation at home. And let it be a small number of students, but the quality of ethical and artistic messages that he would convey to youth would make them free. For this purpose, he shared his time and knowledge with them, and, by and large, perceived it as a vocation of all his life.

Soviet ideology and the method of socialist realism were unacceptable to the artist's mindset. He enables us to feel and comprehend how culture manifests itself in the format of diachrony. The historical context strained the artist, contrasted with his personality and probably pushed Zvirynskyi to inner concentration and implementation of his own artistic potential in the form of isolated nature. Nevertheless, even having isolated himself from reality, the artist still saw himself against the broad background of human culture. Looking into the depths of history, reflecting on the past, building a system of one's own memory as a part of the general cultural memory - these are the personal institutions Zvirynskyi aspired to set up throughout his life.

Analysis of recent research works and publications. The earliest Karlo Zvirynsky-related publications appeared to 1995 in connection with his nomination for the Shevchenko Prize (Mariya Vavrukh, Liubov Voloshyn, Nataliya Kosmolinska, Yevstakhiya Shymchuk, etc.). It is in them that the features of the master's painting style and the originality of his worldview were already outlined. However, the representative genre of these articles deprived them of the opportunity to delve into analysing the works of Zvirynskyi.

The main array of publications about Karlo Zvirynskyi appeared upon his death, and this fact confirms the artist's diachrony 
with his time. It was the beginning of a stage of gradually understanding the role of the artist, as well as restoring his name as the content of the day. Nataliya Kosmolinska attempted to introduce the figure of Zvirynskyi into the 1960s artistic context, with outlining the main range of art searches outside the mainstream [6]. Opposing the official art to those who were on the margins - such a methodological technique was applied by Orest Holubets in his analysing the mid- to late $\mathrm{XX}$ th-century Lviv artistic situation, concerning the creation of K. Zvirynskyi [1]. While continuing to examine the theme of the Lviv artistic centre, O. Holubets tried to formulate factors of uniqueness, however, at the same time, focusing on school differences does not allow to take a look wider and fit leading personalities such as K. Zvirynskyi into the Ukrainian and general European contexts [2].

Roman Yatsiv analyses the Lviv artistic environment against the backdrop of culturological context, looking for a key to understanding both this phenomenon and its main carriers [15]. In such an approach, a view of an isolated society is offset by the power of such individuals as Zvirynskyi, whose thirst for knowledge was capable of finding exclusive routes to replenish information, with giving a sense of remote participation in a common European stream of cultural memory. N. Kosmolynska's monographic sketch about $\mathrm{K}$. Zvirynskyi gives an idea of the artist, his creative method and pedagogical system [7]. There is an analysis of his activities related to sacred art. In general, the format of a composite monograph on the Sixtiers' art expands the possibilities of saliently comprehending the artist's personality.

The artist's daughter Khrystyna Zvirynska-Chaban was the first to introduce into scientific circulation materials about her father's "underground academy" [3]. There is an investigation of a phenomenon of isolation, both internal and external. My first meeting with Kh. Zvirynska-Chaban took place in 2001, when an exhibition of K. Zvirynskyi was planned to be held at the Ukrainian National Art Museum in Kyiv. While scrutinizing his archives, I 
have discovered the greatness of Karlo Zvirynskyi'sthought, which was implemented in word and image. In 2019, we met again with Kh. Zvirynska-Chaban, upon her publishing a monograph on her father and an exhibition of K. Zvirynsky, as well as after the exhibition of K. Zvirynskyi and his "underground academy" had occurred at the Korsak Modern Ukrainian Art Museum in Lutsk. The book of memoirs, interviews, reflections and articles about Karlo Zvirynskyi became a thorough publication, with depicting a full, complete and cordial portrait of the artist against the background of familial, student, and artistic recollections. During a long conversation, it became clear to us that the remembrance of $\mathrm{K}$. Zvirynskyi's name is maintained in a form close to the catacomb one, when the links of this memory do not extend beyond the range of those relative to it. However, the figure of the artist is so significant that its place is not only within the Lviv cultural landscape, but also in the general collective memory. Therefore, there is a huge amount of work ahead to be done in this direction.

The purpose of this research work is to analyses the method of Karlo Zvirynskyi's working in his underground academy, which was based on forming the awareness of reflections on the general cultural memory of humankind. Analysing the system of internal and external apartness makes it possible to grasp the factors that instigated and pushed him to obtaining information and deeply assimilating these sources. Treating the narrative heritage of the artist provides an opportunity to clarify his ideas and their reflections in the form of images. The analysis of his students' thoughts forms a fuller picture of the personality of the artist-teacher. Another task is to identify personality traits that can enable us to understand the figure of K. Zvirynskyi as a component of the Lviv cultural landscape.

Presentation of the main research material. Unfortunately, my approach to Karlo Zvirynskyi's works took place already upon his death. However, I still remember very well the day when I was for the first time in his studio. I was listening to his daughter, 
Khrystyna Zvirynska, and it seemed to me that it was the very story I wanted to listen to. I was all agog to vanish completely among those stories and an atmosphere of the bright studio, where his paintings compactly hung and stood. Later on there were numerous meetings with Khrystyna Zvirynska who kindly enabled me to work with her father's archival materials.

While turning over pages of Karlo Zvirynskyi's memoirs, I was drawn by an expression: In the lifespan of each person, there are the meetings exerting a significant influence on the further course of his life. Had it not been for him - all in him would have gone in a different way. "They open his eyes to what he has not seen before, and it is unknown whether he would have seen it ever. They lend new tints to his understanding of life and his worldview" [13, p. 45].

If to develop the theme of meetings in culture, then in the art of the $20^{\text {th }}$ century, Karlo Zvirynskyi most appreciated Oleksandr Arkhypenko. And it is a significant thing that at a very short interval, such as the changeover of grandeurs of generations of the past century, there were personal exhibitions of both O. Arkhypenko in 2001 and K. Zvirynskyi in 2002 at the National Art Museum of Ukraine in Kyiv. In the same 2002, the Lviv Academy of Arts hosted a conference devoted to the artist The Wall: an Absurd or a Reality; the National Museum of Lviv hosted an exhibition of UkrainianPolish artists Margit and Roman Selskyis, as well as Karlo Zvirynskyi, Andriy Mentukh, and Waclaw Taranczewski; and the catalogue-album "KarloZvirynskyi” was published.

It is unpleasant to state, but the fact is that Karlo Zvirynskyi - as an artist, a teacher, a man of enormous scholarship exerted a significant influence on the Lviv cultural environment. However, his complete inability to conform to the authorities has led to the fact that it was only when Zvirynskyi was 73 that the artist's first exhibition within a joint project with Andriy Mentukh (from Poland) took place at the National Museum of Lviv in 1996. After this exhibition, Karlo Zvirynskyi has been nominated for the Shevchenko Prize, but this nomination was rejected in Kyiv cabinets. 
Karlo Zvirynskyi's painting is fascinating, as a mysterious and obscure space, with its moving living stars. And the concentration of abstract painting spoke like a prayer. "For me, my painting is closely connected with my attitude to God, to my seeing Him, in everything that surrounds me" [4 2002, p. 32]. This probably lies in his uniqueness as an artist, who in the way known solely to him went to the understanding and vision of the great essence of sacred painting, to which he sincerely devoted himself, as well as to abstract painting, the latter uttering by rhythms, pauses, lines, colour combinations, while remaining in its essence the same spiritual language. He came out on the way by which icon painters went as well, and where images encounter abstract forms, and symbols are created.

The distance separating us from K. Zvirynskyi is gradually increasing. Accordingly, the possibility appears to consider his creation not exclusively within the confines of the Lviv artistic situation, and the objectification of his contribution to art grows more real. Zvirynskyi's out-of-time and out-of-style classic gives us a chance to introduce his works into the European artistic context. Therefore, his coming to the public at the turn of the century, only upon his death, is symbolic, which in essence were all his activities. Kh. Zvirynska-Chaban draws our attention: "And nevertheless, while living in conditions of informational isolation, he managed to create in the context of the global art, with leaving behind the following record: 'I will be understood by solely future generations' " $[5$, p. 19].

In 1946, Karlo Zvirynskyi graduated from the Lviv Art and Industry School, where Roman Selskyi was his teacher. Most likely, it was his meeting with Roman Selskyi, from which the then-young Karlo began to nurture the feeling of teaching as a mission. Selskyi and Zvirynskyi have become the closest friends. And Zvirynskyi entered a secluded, elitist artistic environment of the spouses Roman and Magrit Selskyi, where Roman Turyn, Witold Monastyrskyi, sisters Maksymovichs met each Saturday, and conversations on art in 
French and Polish were held. Sometimes talks went outdoors, due to the company's unwillingness to be heard by the KGB.

Undoubtedly, Karlo Zvirynskyi had a gift of communication unlimited to simple words. It was the language of music, plastic art, and silent contemplation. His students said that Karlo Zvirynskyi was a translator of Roman Selskyi. However, the translation should be here considered as the ability to span a bridge between different generations, which itself generates an undivided stream of cultural memory.

Separate records of talks between Selskyi and Zvirynskyi are remained. With all depth and carefulness of those discussions, the most impressive is a level of their correctness. Selskyi adhered to the realistic style and was an atheist, while Zvirynskyi was drawn towards abstraction and was a deeply religious person. In 1990, Roman Selskyi died and Karlo Zvirynskyi recorded: "Out of 87 years of his life, the last 45 - the most important ones - he lives in an «oasis», lives his previous life, spinning a thread of memories that is a reality within this atmosphere" [10, p. 47]. The situation with the generations' cultural memory developing into the protector of human beings from realities of the world has become Karlo Zvirynskyi's existential norm.

In 1949, Zvirinskyi was expelled for a year from the Lviv Institute of Decorative and Applied Arts, for he said in full voice: "One apple of Cézanne is worth more than all the art of socialist realism taken together" [8, p. 17]. That statement embraced truth and, at the same time, juvenile maximalism. He later formulated a mechanism for rejection of the ideologized art: "Socialist realism of Stalin's epoch cast me away to an opposite position - further from naturalism, searching for formalism, to abstraction" [5, p. 201].

The years passed and he would write: "The artist is a special person. $\mathrm{He}$ is endowed with a special vulnerability to his surroundings. He cannot and have no right to remain in the ivory tower at a time when the injustice, untruth, is raging, when the homeland needs the help of each member. There is a time to beat 
ploughshares into swords and a time to beat swords into ploughshares. How may you admire the drawing of an apple when a person dies nearby" $[12$, p. 258]. Zvirynskyi came to understand the significance of the civic stand when it became insufficient to simply remain silent. His intellectual and civil thews were strengthening, while he was clearly circumscribing his artistic standpoint.

By that time, he was already an educated man with a comprehensive erudition. He was well trained in world art, music, literature, philosophy, and religion. His knowledge had been accumulating since his childhood, when he was quite carried away by books from the library of the Basilian Monastery in his native village of Lavriv, Sambir District. Books imbued young Karlo with knowledge, and it was in them that he found advice and consolation in his life full of hunger and cold. As early as in this period, he acquired the skills to escape from reality, discovering a sense in words' strength and abstraction. Having left Lavriv for Lviv at the age of 19, he took with him a concentrated and pulsating image of his childhood and adolescence, on which he would later reflect with his art. Therefore, without any doubt, the first and most important source of his creation was his childhood. These foundations of moral principles, which he obtained in those years, he was able to carry throughout his life. He managed to avoid adaptation to exhibition committees and timeserving policy with respect to power. He was constantly looking for paths that would turn into roads, with subsequent searching for associates while going along these roads points Kh. Zvirynska-Chaban [5, p. 15].

The turning point in Karlo Zvirynskyi's biography was 1957. In art, he was losing touch with the influence of Roman Selskyi's realistic painting and began teaching at the institute, from which he had once been dismissed for rebelliousness. An important influence was the environment of the Selskyi family, where almost all the artists traveled around the world and had received European education. The source of information for him, were broadcasts of the "Voice of America" via the Radio "Liberty" transmitted in Polish 
language, as well as his acquaintance with Andriy Mentukh from Gdansk. He subscribed to all the journals on art in Poland for Zvirynskyi, and sent articles from newspapers. At the time, people in Poland were much more informed about the trends vivid in the artistic world of the West. Although these periodicals had a predominantly negative evaluation of formalistic and abstract searches, they still were a valuable source of information, which Zvyrinskyi thoughtfully worked up.

While working with students, Karlo Zvirynskyi began understanding that in the dominant atmosphere of sluggish and amorphous socialist realism, young people needed to be saved, all the more so he carried a colossal treasure of knowledge, whose sharing was vital for him.

The main goal for Zvirinskyi came to educate citizens whose consciousness would allow them to remain artists, counter to the totalitarian system. In such a peculiar way, he intervened in politics. He collected a group of students, notably Zinoviy Flinta, Andriy Bokotey, Oleh Minko, Liubomyr Medvid, Roman Petruk, Ivan Marchuk, and Bohdan Soyka. All of them came to his one-room apartment where Karlo Zvirynskyi lived together with his wife and three children. Here he conducted classes. Kh. Zvirynska-Chaban wrote: "I remember long walks, of us, three young children, with our mother in the park, and our requests to go home at last. Though, our mother, while looking at the clock, always delayed us for some reason. It was afterwards, over the years, when we understood and found out why it was. In our apartment at the Lysenko Street, students gathered and discussions were held on various topics, as well as one-day exhibitions. It was later - already in the 1990s when those gatherings were called the «underground academy of Zvirynskyi», or the «underground school of Zvirynskyi" [4, p. 7].

The artist himself explained the need for those meetings in such a way: "I saw what students were taught. They were taught bad things, they were not taught what was needed. If they went that way, their talents would be lost and they would be lost as citizens as well. 
And therefore, it seemed to me, I had to do everything to help them preserve their natural endowments and at the same time develop their human dignity, civic awareness. I wanted them to know who they were, what they should do and where to go" [8, p. 17].

Zvirynskyi-teacher and Zvirynskyi-artist were like two wings of one big bird. He explained this condition in such a way: "I would like to emphasize very strongly that ... my work with young people ... it was at the expense of my creativity ..., and further ... I am like an artist, but it turned out that I spent the most time on teaching, on the formation of others than on my own creativity. The times were bad ... It seemed to me that my life was still long, I would paint in plenty, but as I did not explain it to them today, it would be too late tomorrow" [12, p. 260].

The artist repeatedly emphasized that his students were very important to him. The classes had a form of discussion, where various formal approaches were approbated, where young people learned to reflect on what they had seen and heard. And where the teacher tried to prove to them, that there was a current of cultural memory and how important it was to get involved. He was a very tactful person and always tried to see the strengths of students in their works and encourage them. "There is something in it, but..." repeated Zvirinskyi from time to time. He had clear views and convictions, yet he was always open to another thought, if someone could seriously argue it.

Having worked at the Lviv Institute of Decorative and Applied Arts for twenty-five years, he held the position of senior teacher. Nevertheless, students addressed to him exclusively as "Mr. Professor". And it was only after his death that Khrystyna Zvirynskahave received a certificate of awarding him the title of associate professor.

However, before that, there was another sad and, at the same time, significant episode. One year before retirement, Zvirinskyi was removed from teaching. After some time, when Oleh Minko, his student at the "underground academy", became the rector, 
Zvirynskyi resumed work. However, he was still unable to regain himself from that emotional shock. Kh. Zvirynska-Chaban wrote: "He stood firm and believed. A stronger and more faithful person than my father, I did not meet in all my life. He was always able to stand up and give us the belief that everything would be fine. Only upon his death, I understood the price at which all this was given, and from where it all went" [4, p. 9].

Faith in God, self-confidence, belief in his students and certitude in the finality of Soviet ideology invigorated K. Zvirynskyi. Art, as a language of human memory, constantly inspired him. At the end of his life, the artist would write: "In our time, due to a number of factors, the role of art in human life has become especially important. The role of art is not limited to exclusively affecting aesthetic senses, but influences all areas of human life, moral position, living conditions, and feelings" [5, p. 233]. Nowadays, these lines of the artist sound over-optimistic, with our understanding what a pragmatic and feudal-oligarchic system Ukraine has reached during almost 30 years of its Independence. However, Zvirynskyi always believed and this faith lent plenitude to his life without feeling general happiness, yet having personal freedom Thus, his faith is handed over to us and a hope remains that art will become what he bequeathed. We have a responsibility to re-educate ourselves aesthetically and ethically through art.

Church tradition and sacred art meant a great deal to K. Zvirynskyi. However, meditating upon what a level of art began to fill churches after Ukraine gained independence, he sadly stated: "The simplest and perhaps most comprehensive answer was that we did not have our own state. The winds of history rolled us like tumbleweed from side to side, while we permanently borrowed from our neighbors what was worthless for them, with feeling ashamed of shunning the values created by the genius of our people" [5, p. 248].

In addition to working with Karlo Zvirynskyi's archives and talks with his daughter, Khrystyna Zvirynska-Chaban, it was very important for me to hear the memories-reflections of his students, 
who became famous artists. While holding conversations with them, I was impressed by the fact how immediately busy and venerable people responded to my request to tell about their teacher. In the studio of Oleh Minko gathered also Roman Petruk, Andriy Bokotey, and Liubomyr Medvid. We sat for a long time and had recollections, impressions, memories filled with emotions. The following conclusions were outlined:

"We were prodigal sons; we re-realized his greatness when we ourselves became old. We circled time after time and it happened in our own work only to return to Karlo. He did not choose students for their talents; he was like Pissarro, who said that a stone could be taught to draw; but he cultivated a taste, skills and crafts in us via the authentic, the old art. And it was civic position from which he took us for being his disciples".

Roman Petruk.

"In fact, having got behind the walls of the institute, we did not realize the fine art. Zvirynskyi was the first to reveal the world of art, the world of a human-intelligent of a high rank. He was a TEACHER. We flew away from Karlo in our interests as different planets. Now, there is a longing for youth. Those times were incredibly interesting".

Andriy Bokotey.

"Selskyi said that a student should go not further, but otherwise. Zvirynskyi went further. He had an inner need to do good deeds, yet to make them unobtrusively. How much we miss him! Loneliness. There is no one to consult with. And in that there is a great truth".

Oleh Minko.

"His communication with us was a time of maturation of his own talent and creative motivation as well. Because of that, Karlo said that the brush would wait. He had a decent posture at the easel. That was an aristocratic attitude to the process of creation. And it is 
that what brought us up. In his eyes behind thick glasses was fear, intelligence, a secret".

Liubomyr Medvid [9, p. 29].

While analysing the conversation with Andriy Bokotey, Liubomyr Medvid, Oleh Minko and Roman Petruk, we can realize how strong was the influence of K. Zvirynskyi on forming their aesthetic and ethical positions. The artist's mission as a kind of bridge that connects generations and endeavors to hold out against the flow of a would-be true culture and knowledge has been accomplished. Quiet Zvirynskyi, by the power of his personality alone, managed to stand up for what is the standard of humaneness, dignity and ability to learn. Without being a representative of the external ideological system, he was able to form an internal environment, preserving its merit. And the vitality of his environment endures in the activities of his students.

Kh. Zvirynska-Chaban noted: "It is unknown what the face of the 1960s Lviv school would have been like without this chain: Selskyi - Zvirynskyi - a younger generation - "Zvirinskyi's underground academy". The result of an advanced approach of the artist-teacher to educating his students was the emergence of a qualitatively new generation of young artists in Lviv, which determined a new path of development and growth of the Lviv art in the decades to come" [5, p. 19].

Despite the circle of students and his family, at the end of his life, Karlo Zvirynskyi would write: "I am a very lonely person" [13, p. 47]. His loneliness was an island of liberty created with his own hand. That expression was a voice of a great man whose mystery and power went with him. Yet, the dialogue with the Universe continued. "... That what I did could be described as an attempt to walk with the spirit of time. And that is true" [14, p. 53].

Perhaps "sincerity" is the key to every thing that touched Karlo Zvirynskyi. And we already saw the consequences in historical perspective, how strength and sincerity of one particular person 
overcame the walls of ideology. Already over twenty years have gone since his life ended. There is an empty space in downtown Lviv, where once there was a house in which he lived and from where his "underground academy" sprouted. However, the master returns in his creation, which gives us grounds for a different look at the Ukrainian art of the latter half of the $\mathrm{XX}^{\text {th }}$ century. Zvirynskyi was aware of cultural memory's durability, and his students are full of reflections on his name. And his great theoretical work on the methodology of training artists has received a life.

Conclusions. However, the type of memory of Karlo Zvirynskyi still remains in the format of the "catacomb" culture. All who in one or another way have touched the artist's personality, as well as his artistic and epistolary heritages, do understand their worth. Zvirynskyi was fond of mountains, often went to make studies in the Carpathians. As mount Hoverla rises above the mountain ridge, so the figure of Karlo Zvirynskyi retains the spirit of high art and humanity, and the passage of time only more distinctly outlines the master's grandeur. He does deserve to become, in our minds, an essential part of the cultural landscape, a landmark of what is genuine in both life and art.

\section{References}

1. Holubets, O. (2001). Mizh svobodoyu ta totalitaryzmom. Mystetske seredovyshche Lvova druhoyi polovyny XX stolittia [Between Freedom and Totalitarianism. The Lviv Artistic Environment in the Latter Half of the XXth Century]. Lviv: Akademichnyiekspres, 85-86 [in Ukrainian].

2. Holubets, O. (2008). Mystetske seredovyshche Lvova druhoyi polovyny XX - pochatku XXI stolittia: chynnykynepovtornosti [The Lviv Artistic Environment in the Latter Half of the XX th to Early XXI st Century: Factors of Its Singularity] // MystetskamapaUkrayiny. Lviv. Albom [The Art Map of Ukraine. Lviv: An Album]. Kyiv: Yuvelir-pres, 24-25 [in Ukrainian]. 
3. Zvirynska-Chaban, Kh. (1999). Karlo Zvirynskyi i yoho «dukhovna shkola» [KarloZvirynskyi and His «Spiritual School»]. Visnyk LAM, 155-162 [in Ukrainian].

4. Zvirynskyi Karlo: spohady, statti, maliarstvo. 2002. Kataloh [Karlo Zvirynskyi: Recollections, Articles, Painting. A Catalogue], Lviv [in Ukrainian].

5. Zvirynskyi, K. (2017). Vse moy emaliarstvo - to molytva. Spohady, intervyu, rozdumy, statti [All My Painting is a Prayer. Recollections, Interviews, Reflections, and Articles]. Uporiad. Zvirynska-Chaban K. Lviv [in Ukrainian].

6. Kosmolinska, N. (1998). Karlo Zvirynskyi i mystetstvo 1960-kh [Karlo Zvirynskyi and the 1960s Art] // Buklet«Mystetstvo na zlami tysiacholit» ["At the Turn of the Millennia"]. Lviv: Braty Syrotynskii [in Ukrainian].

7. Kosmolinskaya, N. (2015). Zvirinskiy Karlo Yosifovich 1923-1997 [Zvirynskyi Karlo Yosifovich 1923-1997]. Isskustvo ukrainskikh shestidesiatnikov [The Art of the Ukrainian Sixtiers]. Sost. Balashova O., German L. Kyiv: Osnovy, 154-169 [in Russian].

8. Som-Serdyukova, O. (200 2a). Znayomstvo $z$ velychchiu [An Acquaintance with Grandeur]. Dzerkalo tyzhnia [The Mirror Weekly], January, 19 [in Ukrainian].

9. Som-Serdyukova, O. (2002 b). Bih cherez skhodynku Karlo Zvirynskyi [Running across the Step - Karlo Zvirynskyi]. Halereya [The Gallery], 2, 28-29 [in Ukrainian].

10. Som-Serdyukova, O. (2003 a). Karlo Zvirynskyi [Karlo Zvirynskyi]. ANT, 10-12, 120 [in Ukrainian].

11. Som-Serdyukova, O. (2003 b). Zvirynskyi ta "stina" [Zvirynskyi and the "Wall"]. Ukrayinske mystetstvo [The Ukrainian Art], 1, 47 [in Ukrainian].

12. Som-Serdyukova, O. (2005). Karlo Zvirynskyi khudozhnyk, pedahoh: pohliad u maybutnie [Karlo Zvirynskyi, An Artist, A Teacher. A Look into the Future]. MIST, 2, 256-262 [in Ukrainian]. 
13. Som-Serdiukova, O. (2006 a). Bih cherez skhodynku [Running across the Step]. Zhyttia bez arkhivu, 45-48 [in Ukrainian]. 14. Som-Serdyukova, O. (2006 b). Karlo Zvirynskyi: kyyivskyi pohliad [Karlo Zvirynskyi: A View from Kyiv]. Zhyttia bez arkhivu, 49-56 [in Ukrainian].

15. Yatsiv, R. (2008). Obrazotvorche mystetstvo Lvova 1960-kh-1970-kh rokiv: u poshukakh kliuchiv dlia rozuminnia [Fine Arts of Lviv in the 1960s-1970s: Searching for Keys to Understanding]. Mystetska mapa Ukrayiny. Lviv. Albom [The Art Map of Ukraine. Lviv: An Album]. Kyiv: Yuvelir-pres, 28-29 [in Ukrainian].

\section{Олена Миколаївна Сом-Сердюкова,} кандидат мистецтвознавства, доцент,

Ставангер, Норвегія, e-mail: olenasom@gmail.com, ORCID: http://orcid.org/ 0000-0001-5192-545X

\section{КАРЛО ЗВІРИНСЬКИЙ ТА ЙОГО «ПДПІЛЬНА АКАДЕМІЯ»: РЕФЛЕКСІЇ КУЛЬТУРНОЇ ПАМ'ЯТІ}

Анотація. Карло Звіринський (1923-1997 рр.) видатний митець та непересічна особистість. Незаперечним був його вплив на львівське культурне середовище 1960-1990-х рр. Звіринський був тихою людиною, зануреною у власні світи, проте усвідомленість його дій формувала міцне середовище на естетиці європейського мистецтва та етичних нормах християнства. Уважний погляд митця на європейську культуру був пов'язаний із розумінням, що іiі процесами не можна керувати ідеологічно, i, разом 3 тим, що культура існує у безперервності та відображає естетичні та етичні форми людської діяльності. Його пошуки європейської традиції та повне відторження засад соціалістичного реалізму відіграли 
важливу роль у створенні «підпільної академії». Основною метою Звіринського було виховання творчої молоді як громадян, свідомість яких мала б дозволяти їм залишатися митцями всупереч зухвалим викликам суспільства. У коло його учнів входили: Андрій Бокотей, Іван Марчук, Любомир Медвідь, Олег Мінько, Роман Петрук, Богдан Сойка, Зіновій Флінта. Нашим завданням $є$ не бальзамування спадщини «підпільної академії», а спроба створити культурний простір, де можуть відбуватися інтелектуальні рефлексії. Карло Звіринський розумів свою життєву позицію як «я дивлюсь на життя крізь призму книжки» та мистецьку позиції, як «все моє малярство - то молитва». Ставлення до власного життя як до частини цілісного потоку культури сформувало його світобачення. Культурна пам'ять поколінь, що акумулює «сучасність», відігравала для митця територію свободи, яка завжди була його критерієм людського єства. Розуміючи, що пам'ять про Карла Звіринського - це своєрідний камертон морального здоров'я нації, автор робить метою цієї статті ще однією спробою вивести історію про майстра за коло камерної спільноти, що за механізмами дії нагадує катакомбну культуру, в ширший та відкритіший простір, у якому ім'я митця звучало б як частина національного культурного ландшафту.

Ключові слова: художник, «підпільна академія», рефлексія, культурна пам'ять, навчання, освіта, знання, інтелектуальний, естетичний, етичний, культурний ландшафт

\section{Література}

1. Голубець О. Між свободою та тоталітаризмом. Мистецьке середовище Львова другої половини XX століття. Львів: Академічний експрес, 2001. С. 85-86.

2. Голубець О. Мистецьке середовище Львова другої половини XX - початку XXI століття: чинники неповторності // Мистецька мапа України. Львів. Альбом. Київ: Ювелір-прес, 2008. C. 24-25. 
3. Звіринська-Чабан X. Карло Звіринський і його «духовна школа» // Вісник ЛАМ. 1999. С. 155-162.

4. Звіринський Карло: спогади, статті, малярство. Каталог. Львів, 2002, 80 с.

5. Звіринський К. Все моє малярство - то молитва. Спогади, інтерв'ю, роздуми, статті. Упоряд. ЗвіринськаЧабан К. Львів: Манускрипт, 2017. 280 с.

6. Космолінська Н. Карло Звіринський і мистецтво 1960-х. Буклет «Мистецтво на зламі тисячоліть». Львів: Брати Сиротинські і К., 1998.

7. Космолинская Н. Звыринський Карло Йосифович 19231997. Искусство украинских шестидесятников. Сост. Балашова О., Герман Л. Київ: Основи, 2015. С. 154-169.

8. Сом-Сердюкова О. Знайомство 3 величчю. Дзеркало тижня, січня 19, 2002а.

9. Сом-Сердюкова О. Біг через сходинки - Карло Звіринський. Галерея, 2002b, 2. С. 28-29.

10. Сом-Сердюкова О. Карло Звіринський.АНТ, 2003а, 1012, C. 120.

11. Сом-Сердюкова О. Звіринський та «стіна». Українське мистецтво, 2003b, 1, С. 47.

12. Сом-Сердюкова О. Карло Звіринський - художник, педагог: погляд у майбутнє // МІСТ, Київ, 2005, 2, С. 256-262.

13. Сом-Сердюкова О. Біг через сходинку //Життя без архіву, Київ, 2006а. С. 45-48.

14. Сом-Сердюкова О. Карло Звіринський: київський погляд. Життя без архіву, Київ, 2006b, С. 49-56.

15. Яців Р. Образотворче мистецтво Львова 1960-х - 1970-х років: у пошуках ключів для розуміння. Мистецька мапа України. Львів. Альбом. Київ: Ювелір-прес, 2008. С. 28-29. 


\section{Елена Николаевна Сом-Сердюкова,}

кандидат искусствоведения, доцент,

Ставангер, Норвегия, e-mail: olenasom@gmail.com,

ORCID: http://orcid.org/ 0000-0001-5192-545X

\section{КАРЛ ЗВИРИНСКИЙ И ЕГО «ПОДПОЛЬНАЯ АКАДЕМИЯ»: РЕФЛЕКСИИ КУЛЬТУРНОЙ ПАМЯТИ}

Аннотация. Карл Звиринский (1923-1997 гг.) выдающейся художник и незаурядная личность. Его влияние на львовскую культурную среду 1960-1990-х гг. неоспоримо. Звиринский был тихим человеком, живущим миром внутренних размышлений, но осознанность его поступков послужила формированию определенной культурной среды на основах эстетики европейского искусства и этических нормах христианства. Внимательный взгяд художника на европейскую культуру был связан с пониманием того что ее процессами нельзя руководить идеологически, а также осознанием того, что культура существует в непрерывности и отражает эстетические и этические формы человеческой деятельности. Его поиски европейской традиции и полное неприятие устоев социалистического реализма сыграли важную роль в создании «подпольной академии». Основной целью Звиринского было воспитание творческой молодежи как граждан, чье сознание позволило бы оставаться художниками вопреки грубым вызовам общества. В круг его учеников входили Андрей Бокотей, Иван Марчук, Любомир Медвидь, Олег Минько, Роман Петрук, Богдан Сойка, Зиновий Флинта. Нашей задачей является не бальзамирование наследия «подпольной академии», а создание культурного пространства, где могут состояться интеллектуальные рефлексии. Карл Звиринский понимал свою позицию в жизни, как «я смотрю на жизнь сквозь призму книги», а художественную позицию, как «вся моя живопись - 
это молитва». Отношение к собственной жизни, как к части целостного культурного потока сформировало его мировоззрение. Культурная память поколений, которая аккумулирует «современность», значила для художника территорию свободы, которая всегда была его критерием в понимании человеческой природы. Осознавая, что память о Карле Звиринском - это своеобразный камертон нравственного здоровья нации, втор в данной статье осуществил попытку вывести историю о мастере из камерного сообщества, механизмы деятельности которого напоминают катакомбную культуру, в более широкое и более открытое пространство, в котором его имя будет звучать как часть национального культурного ландшафта.

Ключевые слова: художник, «подпольная академия», рефлексия, культурная память, обучение, образование, знания, интеллектуальный, эстетический, этический, культурный ландшафт 